\title{
KESIAPAN BADAN PERTANAHAN NASIONAL KOTA SAMARINDA DALAM PENERBITAN SERTIFIKAT 1 (SATU) LEMBAR (MENURUT PERATURAN MENTERI AGRARIA DAN TATA RUANG / KEPALA BADAN PERTANAHAN NASIONAL NOMOR 7 TAHUN 2016 TENTANG /BENTUK DAN ISI SERTIFIKAT HAK ATAS TANAH)
}

\author{
Muchamad Naufal Zakiy dan Jaidun \\ muchamadnaufalzac@gmail.com, jaidulaw@uwgm.ac.id \\ Fakultas Hukum Universitas Widya Gama Mahakam Samarinda
}

\begin{abstract}
ABSTRAK
Manusia dan tanah punya hubungan yang sangat erat, sangat alami dan tidak terpisahkan.Hal ini dapat dimengerti dan di pahami, karena tanah adalah merupakan tempat tinggal, tempat pemberi makan, tempat mereka dilahirkan, tempat mereka di makamkan, bahkan tempat leluhurnya.Maka selalu adanya pasangan antara manusia dengan tanah, antara masyarakat dengan tanah. Undang-Undang Dasar 1945 Pasal 33 ayat 3 menyebutkan bahwa Bumi, air dan ruang angkasa serta kekayaan alam yang terkandung didalamnya dikuasai oleh Negara dan diperuntukkan untuk sebesar-besarnya kemakmuran rakyat, yang diatur dalam Undang-undang tanah merupakan karunia Tuhan Yang Maha Esa, atas dasar hak menguasai dari Negara, maka menjadi kewajiban bagi pemerintah melaksanakan pendaftaran tanah diseluruh Wilayah Republik Indonesia menurut Undang-Undang Nomor 5 Tahun 1960 tentang Peraturan Dasar Pokok-pokok Agraria yang selanjutnya disebut UUPA yang individualistik komunalistik, religius, selain bertujuan melindungi tanah juga mengatur hubungan hukum hak atas tanah melalui penyerahan Sertifikat sebagai tanda bukti hak atas tanah bagi pemegangnya. Pada Pasal 4 ayat (2) menyebutkan bahwa Sertifikat sebagaimana dimaksud pada ayat (1), dicetak pada 1 (satu) lembar berdasarkan informasi yang diperoleh dari data fisik dan data yuridis serta serta dilengkapi dengan foto pemegang hak yang bersangkutan. Sebagai salah satu kebutuhan pokok masyarakat, pertanahan memiliki peran penting dalam kehidupan masyarakat. Dalam proses memperoleh Sertifikat, proses pelaksanaan pendaftaran tanah harus disesuaikan dengan perkembangan hukum, teknologi dan kebutuhan masyarakat yang diatur dalam Peraturan Menteri Agraria dan Tata Ruang / Kepala Badan Pertanahan Nasional Nomor 7 Tahun 2016 tentang bentuk dan isi Sertifikat hak atas tanah.
\end{abstract}

Kata Kunci : Kesiapan, Sertifikat 1 (satu) lembar, Badan Pertanahan Nasional 


\begin{abstract}
Human and land have a strong relations, very pure and undivided. It can be understood, because land is a home, provide food, birth place, buried place, and home of the ancestor. There are always a relations between human and land, society and a land. The constitution in 1945 article 33 clause 3 mention that earth, water and space with all its contents are controlled by nation and uses for public prosperity, that regulated in land laws are the gift of God almighty, based on rule right from the nation, so its become the government responsibility to perform land registration in all of territory of Republic Indonesia based on law number 5 year 1960 about basic rule of principles of agrarian that further mentioned in UUPA that individualistic, communal, religious, it aims to protect the land and manage the relation of land right through the certificate submission as a proof of land right for it owner. Article 4 clause 2 mention that certificate that mentioned in clause 1 is printed in one sheet based on information from physical and juridical data also equipped by owner's photo. As one of society essential needs, land have an important roles in society lives. In the process of achieving the certificate, land registration process must be adjusted to law and technology development and society needs that regulated in Ministerial Regulation of Agrarian and Spatial / Head of National Land Agency number 7 year 2017 about shape and content of certificate of land right.
\end{abstract}

\title{
Keywords: Readiness, One Sheet Certificate, National Land Agency
}

\section{PENDAHULUAN}

\section{A. Latar Belakang}

Manusia dan tanah punya hubungan yang sangat erat, sangat alami dan tidak terpisahkan.Hal ini dapat dimengerti dan di pahami, karena tanah adalah merupakan tempat tinggal, tempat pemberi makan, tempat mereka dilahirkan, tempat mereka di makamkan, bahkan tempat leluhurnya. Maka selalu adanya pasangan antara manusia dengan tanah, antara masyarakat dengan tanah.Undang-Undang Dasar 1945 Pasal 33 ayat 3 menyebutkan : "Bumi, air dan ruang angkasa serta kekayaan alam yang terkandung didalamnya dikuasai oleh Negara dan diperuntukkan untuk sebesarbesarnya kemakmuran rakyat”. Tanah merupakan karunia Tuhan Yang Maha Esa, atas dasar hak menguasai dari Negara maka menjadi kewajiban bagi pemerintah melaksanakan pendaftaran tanah diseluruh Wilayah Republik Indonesia menurut
Undang-Undang Nomor 5 Tahun 1960 tentang Peraturan Dasar Pokok-pokok Agraria yang selanjutnya disebut UUPA yang individualistik komunalistik, religius, selain bertujuan melindungi tanah juga mengatur hubungan hukum hak atas tanah melalui penyerahan Sertifikat sebagai tanda bukti hak atas tanah bagi pemegangnya.

Mengingat semakin meningkatnya kebutuhan atas tanah bagi kepentinganmasyarakat, sedangkan tanah yang ada di Indonesia tidak bertambah, makadiperlukanlah suatu aturan untuk menjamin kepastian dan perlindungan hukum bagipemegang hak atas tanah, agar dalam pemanfaatan atau penggunaan tanah terjadisuatu keteraturan, antara lain dengan dikeluarkanya UUPA dan Peraturan Pemerintah Nomor24 Tahun 1997 tentang pendaftaran tanahyang selanjutnya disebut 
PP 24/1997 yang menyempurnakan Peraturan Pemerintah Nomor 10 Tahun 1961tentang Pendaftaran tanah.

Menurut Pasal 1 huruf (1) PP 24/1997, pendaftaran tanah ialah rangkaian kegiatan yang dilakukan oleh Pemerintah secara terus menerus, berkesinambungan dan teratur, meliputi pengumpulan, peolahan, pembukuan, dan penyajian serta pemeliharaan data fisik dan data yuridis, dalam bentuk peta dan daftar, mengenai bidang tanah dan satan-satuan rumah susun, termasuk pemberian surat tanda bukti haknya bagi bidang-bidang tanah yang sudah ada hak atas satuan rumah susun serta hak tertentu yang membebaninya. ${ }^{1}$

Pemerintah menyediakan suatu lembaga baru yang dahulunya tidakdikenal dalam hukum adat yaitu lembaga pendaftaran tanahuntuk menjamin kepastian dan perlindungan hukum terhadap pemegang hak atas tanah. Pendaftaran tanahdilakukan sangat berguna bagi pemegang hak atas tanah terutama untuk memperolahbukti kepemilikan hak dengan dikeluarkannya Sertifikat hak atas tanah yang berlakusebagai alat pembuktian yang kuat hal ini diatur dalam Pasal 19 UUPA yang menyebutkan :

1. Untuk menjamin kepastian hukum oleh pemerintah diadakan pendaftarantanah di seluruh wilayah Republik Indonesia menurut ketentuan-ketentuanyang diatur dalam Peraturan Pemerintah.

2. Pendaftaran tanah dalam ayat (1) Pasal ini meliputi :
a. Pengukuran, perpetaan dan pembukuan tanah;
b. Pendaftaran hak-hak atas tanah dan peralihan hak-hak tersebut;

1 Samun Ismaya, Hukum Administrasi Pertanahan, Graha Ilmu, Yogyakarta, 2013, Hal 93 c. Pemberian surat-surat tanda bukti hak, yang berlaku sebagai alatbukti yang kuat.

Pasal 19 Undang-undang Pokok Agraria tersebut diatas bisa dilihat bahwa pandaftaran tanah itu sangat penting untuk dilaksanakan bagi seluruhrakyat Indonesia serta bagi pihak-pihak yang berkepentingan baik perorangan maupunbadan hukum di seluruh wilayah Republik Indonesia demi terjaminnya kepastianhukum dan kepastian hak atas tanah bagi pemegang hak atas tanah itu sendiri antaralain :

1. Bagi pihak pemilik tanah dimana dalam hal ini pemilik tanah diberikanSertifikat tanah sebagai alat bukti yang kuat tentang data fisik dan datayuridis, sehingga pemilik tanah dengan mudah membuktikan hak atastanahnya.

2. Bagi pihak ketiga terhadap tanah yang bersangkutan, biasanya kreditur ataupembeli dengan mudah dapat diperoeh data atau keterangan yang dapatdipercaya baik data fisik maupun data data yuridis.

3. Bagi Pemerintah atau Negara lebih mudah untuk mengadakan perencanaanpembangunan atau pengawasan terhadap hak atas tana tersebut.

Ketentuan lebih lanjut terhadap pentingnya pendaftaran tanah untuk menjamin kepastian hukum hak atas tanah masyarakat dibuktikan dengan adanya Sertifikat Hak atas tanah yang ditentukan dalam Pasal 32 ayat (1) PP 24/1997 yang menyebutkan : "Sertifikat merupakan surat tanda bukti hak yang berlaku sebagai alat pembuktian yang kuat mengenai data fisik dan data yuridis yang termuat didalamnya, sepanjang data fisik dan data yuridis tersebut sesuai dengan data yang ada dalam surat ukur dan buku tanah yang bersangkutan." 
Berdasarkan isi Pasal tersebut di atas Sertifikat merupakan surat tanda buktihak yang kuat yang berarti bahwa selama tidak dapat dibuktikan sebaliknya data fisikdan data yuridis yang tercantum didalamnya harus diterima sebagai data yang benar.Sebagaimana juga dapat dibuktikan dari data yang tercantum dalam buku tanah dan surat ukurnya. Jadi didalam penguasaan suatu bidang tanah Sertifikat hak atas tanah sangat penting untuk dimiliki demi terciptanya suatu kepastian dan perlindungan hukum terhadap pemegangnya.

Ketentuan mengenai bentuk, isi, dan format Sertifikat hak atas tanah dengan berlakunya Peraturan Menteri Agraria dan Tata Ruang / Kepala Badan Pertanahan Nasional Nomor 7 Tahun 2016 tentang bentuk dan isi Sertifikat hak atas tanah yangselanjutnya disebut Permen ATR No. 7/2016pada tanggal 2 Maret 2016, menggantikan bentuk, isi, dan format Sertifikat hak atas tanah yang sebelumnya yang diatur didalam Peraturan Menteri Negara Agraria/Kepala Badan Pertanahan Nasional Nomor 3 Tahun 1997Tentang Ketentuan Pelaksanaan Peraturan Pemerintah Nomor 24 Tahun 1997Tentang Pendaftaran Tanah.

Penggantian bentuk dan isi Sertifikat yang lama ke bentuk dan isi Sertifikat baru akan dilakukan secara bertahap, sesuai dengan kesiapan Kantor Pertanahan. Kantor Pertanahan paling lama dua tahun sejak berlakunya Permen ATR No. 7/2016, wajib menerima permohonan perubahan format Sertifikat, Sertifikat yang lama tetap sah dan berlaku. Blanko Sertifikat lama (sebelum berlakunya Permen ATR No. 7/2016) yang masih tersedia di Kantor Pertanahan masih dapat dipergunakan sampai persediaan blanko tersebut habis sebagaimana yang ketentuan Pasal 8 ayat (1) dan ayat (2) Permen ATR No. 7/2016.

Penggantian bentuk dan isi Sertifikat dengan format sebelumnya yang ada pada pemegang hak atas tanah ke dalam bentuk dan isi Sertifikat seperti yang diatur dalam Peraturan Menteri Agraria dan Tata Ruang / Kepala Badan Pertanahan Nasional Nomor 7 Tahun 2016 tentang bentuk dan isi Sertifikat hak atas tanah akan dilakukan secara bertahap sesuai dengan kesiapan kantor pertanaan dalam waktu maksimal 2 (dua) tahun sejak peraturan ini berlaku, Kantor Pertanahan wajib menerima permohonan perubahan format Sertifikat. Sertifikat yang menggunakan bentuk, isi dan format sebelum berlakunya Permen ATR No. 7/2016 masih tetap dianggap sah dan berlaku blanko Sertifikat yang masih tersedia di kantor pertanahan, sebelum Permen ATR No. 7/2016 berlaku masih dapat dipergunakan sampai persediaan blanko tersebut habis. ${ }^{2}$

Diundangkannya Permen ATR No. 7/2016 pada tanggal 2 Maret 2016, maka bentuk, isi, dan format Sertifikat dicetak menjadi 1 (satu) lembarberdasarkan informasi yang diperoleh dari data fisik dan data yuridis serta dilengkapi dengan foto pemegang hak yang bersangkutan. Sebagai salah satu kebutuhan pokok masyarakat, pertanahan memiliki peran penting dalam kehidupan masyarakat. Dalam proses memperoleh Sertifikat, proses pelaksanaan pendaftaran tanah harus disesuaikan dengan perkembangan hukum, teknologi dan kebutuhan masyarakat. Melalui Permen

2 www.bpn.go.id. Kementrian ATR/BPN Keluarkan Peraturan Sertifikat Satu Lembar, 12 Agustus 2017, pukul 21.51 WITA 
ATR No. 7/2016, Menteri Agraria dan Tata Ruang/Kepala Badan Pertanahan Nasional mengatur bentuk dan isi Sertifikat hak atas tanah beserta sistem Komputerisasi Kegiatan Pertanahan selanjutnya disebut KKP yang merupakan sistem elektronik pendaftaran tanah.

Permen ATR No. 7/2016 mencabut ketentuan bentuk dan isi Sertifikat dalam Peraturan Menteri Negara Agraria/Kepala badan Pertanahan Nasional Nomor 3 tahun 1997 tentang Ketentuan Pelaksanaan Peraturan Pemerintah Nomor 24 tahun 1997 tentang Pendaftaran Tanah, untuk menjamin kepastian hukum pelaksanaan dan penerapan Permen ATR No. 7/2016 dalam penyeragaman bentuk, isi dan format Sertifikat hak atas tanah, maka tentunya kesiapan dari Badan Pertanahan Nasional untuk menerapkan Permen ATR No. 7/2016 tersebut sangat dibutuhkan selaku pihak penyelenggara pendaftaran tanah.

\section{B. Rumusan Masalah}

Adapun masalah dalam peneitian ini antara lain :

1. Bagaimana kesiapan Badan Pertanahan Nasional Kota Samarinda dalam penerbitan Sertifikat 1 (satu) lembar menurutPeraturan Menteri Agraria Dan Tata Ruang / Kepala Badan Pertanahan Nasional Nomor 7 Tahun 2016 tentang bentuk dan isi Sertifikat hak atas tanah?

2. Apakah kendala-kendala yang dihadapi Badan Pertanahan Nasional Kota Samarinda dalam penerbitan Sertifikat 1 (satu) lembar menurutPeraturan Menteri Agraria Dan Tata Ruang / Kepala Badan Pertanahan Nasional Nomor 7 Tahun 2016 tentang bentuk dan isi Sertifikat hak atas tanah?

\section{Tujuan dan Manfaat Penelitian}

Adapun penelitian ini bertujuan untuk mengetahui bentuk kesiapan Badan Pertanahan Nasional dalam penerbitan Sertifikat 1 (satu) lembar menurut Permen ATR No. 7/2016 tentang bentuk dan isi Sertifikat hak atas tanah dan untuk mengetahui kendala-kendala yang dihadapi Badan Pertanahan Nasional dalam penerbitan Sertifikat 1 (satu) lembar menurut Permen ATR No. 7/2016 tentang bentuk dan isi Sertifikat hak atas tanah

Adapun penelitian ini diharapkan dapat memberikan Manfaat baik secara teoritis maupun praktisi Manfaat Teoritis untuk menambah pengetahuan dan melengkapi bahan bacaan dalam ilmu hukum, serta ilmu pengetahuan khususnya dalam ilmu Hukum Pertanahan.yang berkaitan dengan obyek penelitian, yaitu Kesiapan Badan Pertanahan Kota Samarinda Dalam Penerbitan Sertifikat 1 (Satu) Lembar menurutPermen ATR No. 7/2016 tentang bentuk dan isi Sertifikat hak atas tanah, dan Manfaat Praktis sebagai bahan informasi kepada Badan Pertanahan Nasional mengenai penyeragaman penerbitan bentuk isi dan format Sertifikat yang baru setelah ditetapkannya Permen ATR No. 7/2016, dan sebagai bahanpengembangan pemikiriran informasi kepada masyarakat bahwa setelah ditetapkannya Permen ATR No. 7/2016 masyarakat wajib menggati bentuk dan isi Sertifikat dengan format sebelum berlakunya Permen ATR No. 7/2016 ini yang ada pada pemegang hak atas tanah ke bentuk dan isi Sertifikat sebagaimana diatur dalam Permen ATR No. 7/2016.

\section{METODE PENELITIAN}

\section{Jenis Penelitian dan Sumber Data \\ Penelitian ini menggunakan jenis penelitian Yuridis Normatif, yaitu Penulisan skripsi ini merupakan tipe}


normatif (dogmatic research) yakni mencari kebenaran dalam ilmu hukum dengan melihat peraturan-peraturan yang tertulis menjadi objek utama kajiannya. ${ }^{3}$ Yuridis Normatif, yaitu pendekatan yang menggunakan konsepsi legis positivis. Konsep ini memandang hukum identik dengan norma-norma tertulis yang dibuat dan diundangkan oleh lembaga atau pejabat yang berwenang. Konsepsi ini memandang hukum sebagai suatu sistem normatif yang bersifat mandiri, tertutup dan terlepas dari kehidupan masyarakat yang nyata. ${ }^{4}$

Bahan hukum yang dibutuhkan dalam penelitian ini adalah Bahan Hukum Primer yaitu bahan hukum yang menjadi dasar kajian dalam penelitian ini yakni Undang Undang Dasar 1945 Amandemen IV, Undang Undang Pokok Agraria Nomor 5 Tahun 1960 Peraturan Dasar PokokPokok Agraria, Peraturan Pemerintah Republik Indonesia Nomor 40 Tahun 1996 Tentang Hak Guna Usaha, Hak Guna Bangunan, dan Hak Pakai Atas Tanah, Peraturan Pemerintah Republik Indonesia Nomor 24 Tahun 1997 Tentang Pendaftaran Tanah, Peraturan Presiden Republik Indonesia Nomor 20 Tahun 2015 tentang Badan Pertanahan Nasional.

Bahan Hukum Sekunder, Bahan hukum sekunder adalah data pendukung atau penunjang pembahasan daripada permasalahan yang akan diteliti,sumber data Sekunder yang terutama adalah bukubuku hukum termasuk Skripsi, tesis, dan disertasi hukum serta jurnal-jurnal hukum $^{5}$.sumber data sekunder yang digunakan untuk membantu memahami berbagai konsep hukum dalam sumber data

${ }^{3}$ Suratman dan Philips Dillah,Metode Penelitian Hukum, Alfabeta, Bandung, 2013, Hal 54

${ }^{4}$ Johnny Ibrahim, Teori dan Metode Penelitian Hukum Normatif, Bayumedia Publishing, Malang, 2006, Hal. 295

${ }^{5}$ Marzuki Mahmud Peter, Penelitian Hukum Edisi Revisi, Jakarta, Prenada Media Group, 2016, Hal. 195-196 primer, analisis bahan hukum primer dibantu oleh sumber data sekunder yang diperoleh dari berbagai sumber baik jurnal, buku-buku, serta karya ilmiah lainnya yang terkait dengan permasalahan yang diangkat. Dan Bahan HukumTersier, Bahan hukum tersier adalah data bersifat menunjang dari data primer dan data sekunder yaitu berupa istilah istilah yang diperoleh dariInternet yang berhubungan dengan permasalahan yang menjadi objek penelitian dalam penulisan proposal Skripsi ini.

\section{Teknik Pengumpulan Data}

Metode dan teknik dalam pengumpulan data yang digunakan dalam penelitian ini adalah Study kepustakaan dengan mengkaji buku-buku yang relevan dengan permasalahan yang penulis angkat dan yang relevan dengan objek yang penulis angkat dan wawancara dengan narasumber yang terkait dengan penelitian ini.

\section{Analisa Data}

Menurut Beni Ahmad Soebani yang ditulis dibuku yang berjudul Metode Penelian Hukum menyatakan bahwa analisa data adalah pengolahan data yang diperoleh dari penelitian pustaka maupun penelitian lapangan. Terhadap data primer yang didapat dari lapangan terlebih dahulu diteliti kelengkapannya dan kejelasannya untuk diklasifikasi serta dilakukan penyusunan secara sistematis serta konsisten untuk memudahkan melakukan analisis. Data primer inipun terlebih dahulu di korelasi untuk menyelesaikan data yang paling relevan dengan perumuan permasalahan yang ada dalam penelitian ini.Data sekunder yang didapat dari kepustakan dipilih serta dihimpun secara sistematis, seingga dapat dijadikan acuan dalam melakukan analisis. Dari hasil data penelitian pustaka maupun lapangan ini 
dilakukan pembahasan secara deskriptif analitis. $^{6}$

\section{PEMBAHASAN}

A. Kesiapan Badan Pertanahan Nasional Kota Samarinda Dalam Penerbitan Sertifikat 1 (Satu) Lembar (Menurut Peraturan Menteri Agraria Dan Tata Ruang / Kepala Badan Pertanahan Nasional Nomor 7 Tahun 2016 Tentang Bentuk Dan Isi Sertifikat Hak Atas Tanah)

Pada hakikatnya Sertifikat merupakan surat tanda bukti hak sebagaimana dimaksud dalam Pasal 19 ayat (2) huruf c UUPA, Sertifikat merupakan produk hukum dalam hal ini Badan Pertanahan Nasional bertanggunggungjawab atas segala perubahan / penyeragaman yang berkaitan dengan perubahan bentuk dan isi sertifikat. Sertifikat merupakan tanda bukti hak kepemilikan atas tanah yang sah maka Badan Pertanahan Nasional bertanggungjawab akan kesiapan penerbitan sertifikat 1 (satu) lembar menurut Permen ATR No. 7/2016 tentang bentuk dan isi sertifikat hak atas tanah.

Dengan berdasar ketentuan Pasal 19 UUPA, khususnya ayat (1) dan (2), dapat diketahui bahwa dengan pendaftaran tanah/pendaftaran hak-hak atas tanah, sebagai akibat hukumnya maka pemegang hak yang bersangkutan akan diberikan surat tanda hak atas tanah dan berlaku sebagai alat pembuktian yang kuat terhadap pemegang hak atas tanah tersebut. Sesuai yang diamanatkan oleh Undang Undang Nomor 5 Tahun 1960 tentang Peraturan pokok-pokok Agraria dan Peraturan Pemerintah Nomor 24 Tahun 1997

6 Beni Ahmad Soebani, Metode Penelitian Hukum, Pustaka Setia, Bandung, 2009, Hal. 103 tentang Pendaftaran Tanah, telah diterbitkan Peraturan Menteri Nomor 3 Tahun 1997 tentang Ketentuan Pelaksanaan Peraturan Pemerintah Nomor 24 Tahun 1997 tentang pendaftaran Tanah.

Berdasarkan Pasal 2 PP 24/1997 tentang pendaftran tanah pelaksanaan pendaftaran tanah berdasarkan azas sederhana, aman terjangkau, mutakhir dan terbuka, pendaftaran tanah disimpan dan disajikan secara elektronik, maka ketentuan dalam Peraturan Menteri Nomor 3 Tahun 1997 yang di perbarui dengan Permen ATR No. 7/2016 terkait bentuk dan isi Sertifikat hak atas tanah, perlu disesuaikan dengan perkembangan hukum, teknologi dan kebutuhan masyarakat. Sifat pembuktian sertifikat sebagai tanda bukti hak yang tertuang dalam Pasal 32 ayat (1) dan (2) Peraturan Pemerintah Nomor 24 Tahun 1997 Tentang Pendaftaran Tanah :

1. Sertipikat merupakan surat tanda bukti hak yang berlaku sebagai alat pembuktian yang kuat mengenai data fisik dan data yuridis yang termuat di dalamnya, sepanjang data fisik dan data yuridis tersebut sesuai dengan data yang ada dalam surat ukur dan buku tanah hak yang bersangkutan.

2. Dalam hal atas suatu bidang tanah sudah diterbitkan sertipikat secara sah atas nama orang atau badan hukum yang memperoleh tanah tersebut dengan itikad baik dan secara nyata menguasainya, maka pihak lain yang merasa mempunyai hak atas tanah itu tidak dapat lagi menuntut pelaksanaan hak tersebut apabila dalam waktu 5 (lima) tahun sejak diterbitkannya sertipikat itu tidak mengajukan keberatan secara tertulis kepada pemegang sertipikat dan Kepala Kantor Pertanahan yang bersangkutan ataupun tidak mengajukan gugatan ke Pengadilan 
mengenai penguasaan tanah atau penerbitan sertipikat tersebut.

Adapun unsur-unsur kesiapan dari Badan Pertanahan Nasional Kota Samarinda dalam penyeragaman Permen ATR No. 7/2016 tentang bentuk dan isi sertifikat hak atas tanah yaitu :

\section{Kesiapan Organisasi}

Kesiapan organisasi Badan Pertanahan Kota Samarinda dalam penerbitan sertifikat 1 (satu) lembar membutuhkan organisasi yang memang diperuntukkan untuk mengurus bentuk dan isi Sertifikat hak atas tanah format yang lama dan diganti dengan bentuk dan isi Sertifikat hak atas tanah dengan format yang baru dalam bentuk Sertifikat 1 (satu) lembar.

Untuk perubahan format Sertifikat yang lama ke bentuk yang baru yang berbentuk 1 (satu) lembar pengaturannya diatur dalam Peraturan Menteri Agraria Dan Tata Ruang / Kepala Badan Pertanahan Nasional Nomor 7 Tahun 2016 Tentang Bentuk Dan Isi Sertifikat Hak Atas Tanah.

Bahwa dalam hal ini Badan Pertanahan Nasional kota samarinda mengatakan bahwa telah siap mengenai perubahan format bentuk isi Sertifikat yang lama ke bentuk Sertifikat yang baru selagi ketentuan pelaksananya sudah terbit dari pusat. Berdasarkan penjelasan diatas maka mekanisme perubahan bentuk sertifikat sebelum di undangkannya Permen ATR No 7/2016 yaitu sertifkat yang lama masih tetap berlaku namun harus diseragamkan dengan peraturan yang baru sesuai dengan amanat Pasal 19 UUPA yang menyebutkan:

1. Untuk menjamin kepastian hukum oleh pemerintah diadakan pendaftaran tanah di seluruh wilayah Republik Indonesia menurut ketentuanketentuan yang diatur dalam Peraturan Pemerintah.
2. Pendaftaran tanah dalam ayat (1) Pasal ini meliputi :

a. Pengukuran, pemetaan dan pembukuan tanah ;

b. Pendaftaran hak-hak atas tanah dan pemeliharaan hak-hak tersebut ;

c. Pemberian surat-surat tanda bukti hak, yang berlaku sebagai alat bukti yang kuat.

\section{Kesiapan Sistem}

Kesiapan Badan Pertanahan Kota Samarinda Dalam Penerbitan Sertifikat 1 (Satu) Lembar dilaksanakan menggunakan system penunjang yaitu Kegiatan Komputerisasi Pertanahan (KKP) yang sudah lama dilaksanakan sebelum diundangkannya Permen ATR No. 7/2016 yaitu sejak Tahun 2012 yang hingga sampai sekarang masih digunakan untuk penunjang penerbitan Sertifikat.Aplikasi sistem KKP Badan Pertanahan Kota Samarinda ini hanya boleh dilakukan oleh pejabat Badan Pertanahan Nasional.Sehingga yang mampumengoperasikan aplikasi tersebut hanya pejabat Badan Pertanahan Nasional.

Aplikasi Sistem KKP merupakan aplikasi yang dikembangkan BadanPertanahan Nasional Kota Samarinda dalamrangka meningkatkan kualitas pendaftaran tanah secara cepat.Fitur-fitur yang ada dalam aplikasi KKP ini dibuat sederhana dan user friendly sehinggamemudahkan pengguna dalam mengoperasikan aplikasi KKP.

\section{Kesiapan Sumber Daya Manusia (SDM) \\ Salah satu faktor yang} mempengaruhi Kesiapan organisasi Badan Pertanahan Nasional Kota Samarinda dalam penerbitan sertifikat 1 (satu) lembar adalah sumber daya manusia (SDM) pengelola itu sendiri. Untuk mengukur SDM Badan Pertanahan Nasional Kota Samarinda dapat pula dilihat dari aspek pengalaman 
danpendidikannya serta pelatihan-pelatihan yang mereka karena sebagian pejabat Badan Pertanahan Nasional Kota Samarinda banyak yang belum mengetahui adanya peraturan baru yang mengatur tentang perubahan bentuk dan format Sertifikat yang baru yang berbentuk 1 (satu) lembar.

\section{Kesiapan Sarana dan Prasarana}

Dalam proses kesiapan sarana dan prasaran Badan Pertanahan Nasional Kota Samarinda telah siap menghadapi perubahan bentuk dan isi Sertifikat baru yang berbentuk 1 (satu) lembar dengan menyiapkan kebutuhan antara lain seperti: komputer, laptop, jaringan internet, hardisk, printer sarana dan prasarana tersebut sudah tersedia dan kualitasnya pun terjamin.

Kesiapan Badan Pertanahan Nasional Kota samarinda mengenai kesiapan penerbitan sertifikat 1 (satu) lembar yang diamanatkan oleh Permen ATR No.7/2016 dalam hal ini Badan Pertanahan Nasional Kota samarinda masih menggunakan format bentuk dan isi sertifikat hak atas tanah dengan banko yang lama.

Dari penjelasan diatas dapat disimpulkan bahwa Badan Pertanahan Nasional Kota samarinda belum melaksanakan penyeragaman menurut Pasal 4 ayat (2) Permen ATR No 7/2016 tentang bentuk dan isi sertifikat hak atas tanah yang di cetak pada 1 (satu) lembar berdasarkan informasi yang diperoleh dari data fisik dan data yuridis. Badan Pertanahan Nasional Kota samarinda juga belum siap melaksanakan Permen ATR No 7/2016 tentang bentuk dan isi sertifikat hak atas tanah karena masih menggunakan format dan blako sebelum di undangkanya Permen ATR No 7/2016.

Penyeragaman mengenai bentuk dan isi sertifikat yang lama dengan sertifikat yang baru yang seharusnya sebagai berikut:
1. Bentuk dan Isi Sertifikat Lama

Sertifikat tanah hak milik wajib berisikan dua bagian utama yaitu Buku Tanah dan Surat Ukur. Sedangkan Sertifikat hak milik atas satuan rumah susun harus berisikan empat bagian utama yaitu:

a). Salinan buku tanah

b). Salinan surat ukur Tanah Hak Bersama

c). Gambar denah tingkat rumah susun yang bersangkutan yang menunjukkan satuan rumah susun yang dimiliki, dan

d). Pertelaan/uraian mengenai besarnya hak milik atas bagian bersama, benda bersama dan tanah bersama yang bersangkutan. Semua bagianbagian dari Sertifikat-Sertifikat tersebut ada arsipnya dan dipelihara baik-baik di Kantor Pertanahan.

Untuk menjamin keamanan, kepastian dan perlindungan hukum bagi para pemilik Sertifikat, Kantor Pertanahan meneylenggarakan suatu penatausahaan pendaftaran tanah dengan antara lain menyelenggarakan, menyimpan dan memelihara apa yang disebut dengan Daftar Umum, yang terdiri dari enam daftar yaitu;

1. Daftar Nama;

2. Daftar Tanah;

3. Daftar Buku Tanah;

4. Daftar Surat Ukur;

5. Daftar Denah satuan rumah susun; dan Daftar Salinan Sertifikat Hak Milik atas Satuan Rumah Susun

\section{Bentuk dan Isi Sertifikat Baru}

Sertifikat hak atas tanah diberikan untuk kepentingan pemegang hak atau pengelola tanah.Menurut Pasal 4 ayat (2) Peraturan Menteri Nomor 7 Tahun 2016 mengatur ketentuanbentuk dan kriteria Sertifikat hak atas tanah yang berbunyi, Sertifikat hak atas tanah dicetak pada 1(satu) lembar kertas berdasarkan informasi 
yang diperoleh dari data fisik dan data yuridis".

Bentuk dan ukuran lembar Sertifikat bisa dilihat di lampiran Pasal 4 ayat (3)ATR No. 7/2016 yang benrbunyi, Sertifikat hak atas tanah harus memuat informasi sebagai berikut:

a). Nama pemegang hak atas tanah, khusus Sertifikat untuk perorangan juga harus dilengkapi foto pemegang hak yang bersangkutan;

b). Jenis hak atas tanah;

c). Nomor identifikasi bidang tanah;

d). Nomor induk kependudukan/nomor identitas;

e). Tanggal berakhirnya hak, untuk hak atas tanah dengan jangka waktu;

f). Kutipan peta pendaftaran;

g). Tanggal penerbitan; dan

h). Pengesahan

Penggantian bentuk dan isi Sertifikat dengan format sebelumnya yang ada pada pemegang hak atas tanah ke dalam bentuk dan isi Sertifikat seperti yang diatur dalam Permen ATR No. 7/2016 akan dilakukan secara bertahap sesuai dengan kesiapan kantor pertanahan. Dalam waktu maksimal 2(dua) tahun sejak peraturan ini berlaku, kantor pertanahan wajib menerima permohonan perubahan format Sertifikat. Sertifikat yang menggunakan bentuk, isi dan format sebelum berlakunya Permen ATR No. 7/2016 masih tetap dianggap sah dan berlaku.Blanko Sertifikat yang masih tersedia di kantor pertanahan, sebelum Permen ATR No. 7/2016 berlaku masih dapat dipergunakan sampai persediaan blanko tersebut habis.

Berdasarkan penjelasan pengertian sertifikat tersebut diatas, maka dapat diketahui bahwa sertifikat hak atas tanah yang baru akan meberikan kepastian hukum hak atas tanah bagi pemegang hak atas tanah tersebut yang berkenaan dengan penerbitan sertifikat 1 (satu) lembar yang saat ini belum terlaksana oleh Badan Pertanahan Nasional Kota Samarinda.

Dalam hal ini Kementerian Agraria dan Tata Ruang / Badan Pertanahan Nasional (ATR/BPN) secara resmi mengeluarkan peraturan terbaru tentang perubahan bentuk sertifikat hak atas tanah yang mulai berlaku sejak tanggal 2 Maret 2016. Berdasarkan Peraturan Menteri Agraria dan Tata Ruang / Kepala Badan Pertanahan Nasional Nomor 7 tahun 2016 Tentang Bentuk Dan Isi Sertifikat Hak Atas Tanah, perubahan ini dilakukan untuk menyesuaikan perkembangan hukum, teknologi dan kebutuhan masyarakat. Kebijakan ini turut mendukung pelaksanaan pendaftaran tanah yang sederhana, aman, terjangkau, mutakhir dan terbuka. Nantinya secara bertahap data pendaftaran tanah akan disimpan dan disajikan secara elektronik.

Permen ATR No. 7/2016 mengatur pembuatan sertifikat yakni surat tanda bukti hak untuk hak atas tanah, hak pengelolaan, tanah wakaf, hak milik atas satuan rumah susun dan hak tanggungan yang masingmasing sudah dibukukan dalam buku tanah. Sertifikat akan dicetak pada satu lembar berdasarkan informasi yang diperoleh dari data fisik dan data yuridis serta dilengkapi dengan foto pemegang hak yang bersangkutan.

Pada bidang sertifikat akan tertera informasi antara lain: nama pemegang hak atas tanah, jenis hak atas tanah, nomor identifikasi bidang tanah, nomor induk kependudukan / nomor identitas, tangal berakhir hak - untuk hak atas tanah dengan jangka waktu, kutipan peta pendaftaran, tanggal penerbitan dan pengesahan. Kutipan peta pendaftaran yang dimaksud adalah data spasial tervalidasi dari bidang tanah dan membuat sekurang-kurangnya infomasi tentang geometri, luas dan letak tanah.

Dengan demikian, maka penerbitan sertifikat 1 (satu) lembar merupakan upaya 
untuk mencapai pelaksanaan terhadap peraturan dan persyaratan dalam ketentuan hukum yang berlaku secara umum dan individual, melalui penyeragaman mengenai Permen ATR No. 7/2016 tentang bentuk dan isi sertifikat hak atas tanah. Dalam hal ini Badan Pertanahan Nasional Kota Samarinda masih menggunakan bentuk format yang tersebut $\mathrm{di}$ atas dikarenakan karena adanya faktor-faktor penghambat karena belum di terbitkannya sertifikat 1 (satu) lembar.

\section{B. Kendala-kendala yang dihadapi Badan Pertanahan Nasional Kota Samarinda Dalam Penerbitan Sertifikat 1 (Satu)}

Kesiapan Badan Pertanahan Nasional

Kota Samarinda dalam penerbitan sertifikat 1 (satu) lembar dapat dilaksanakan dengan baik tentunya harus didukung diantaranya oleh Sumber Daya Manusia yang berkompeten. Dalam melaksanakan pernerbitan sertifikat 1 (satu) tentunya tidak selalu berjalan dengan mulus, tetapi ada kendala-kendala yang dihadapi baik kendala dari Internal pelaksana pengelola itu sendiri maupun kendala yang sifatnya datang dari luar (Eksternal).

Adapun kendala-kendala yang dihadapi Badan Pertanahan Nasional Kota Samarinda dalam kesiapan penerbitan Sertifikat 1 (satu) lembar yaitu internal Badan Pertanahan Nasional Kota Samarinda mengenai kapasitas Badan Pertanahan Nasional Kota Samarinda seperti kendala-kendala sebagai berikut :

1. Seperti belum ditetapkannya petunjuk pelaksana dalam pelaksanaan Permen ATR No. 7/2016 mengenai pelaksanaan penerbitan sertifikat 1 (satu) lembar oleh Menteri Agraria dan Tata Ruang karena ada faktor-faktor internal yang dalam pelaksanaan penerbitan sertifikat 1 (satu) lembar tersebut belum terlaksana di Badan
Pertanahan Nasional Kota Samarinda sehingga dalam hal ini Badan Pertanahan Nasional Kota Samarinda belum mengetahui aturan-aturan yang dipergunakan untuk pelaksanaan Permen ATR No. 7/2016 mengenai sertifikat 1 (satu) lembar.

2. Belum adanya petunjuk teknis dari Permen ATR No. 7/2016 mengenai sertifikat 1 (satu) lembar sehingga Badan Pertanahan Nasional Kota Samarinda belum mengetahui bentuk dan isi sertifikat 1 (satu) lembar yang diamanat oleh Permen ATR No. 7/2016.

3. Blanko pendaftaran tanah yang disediakan oleh Kantor Badan Pertanahan Nasional Kota Samarinda masih menggunakan bentuk blanko sertifikat sebelum di undangkannya Permen ATR No. 7/2016.

Adapun kendala-kendala tersebut diatas meupaka suatu kejanggalan yang dialami Badan Pertanahan Nasional Kota Samarinda dalam penerbitan sertikat 1 (satu) lembar sehingga Badan Pertanahan Nasional Kota Samarinda sampai sekarang masih belum mempersiapkan sedikitpun mengenai penerbitan sertifikat 1 (satu) lembar yang diamanatkan Permen ATR No. 7/2016 tentang bentuk dan isi sertifikat hak atas tanah.

Berdasarkan penjelasan diatas dapat disimpulkan bahwa kendala-kendala yang dialamai Badan Pertanahan Nasional Kota Samarinda yaitu mengenai aturan-aturan yang belum diterbitkan dari pusat untuk pelaksanaan penerbitan sertifikat 1 (satu) lembar karena terbenturnya suatu kebijakan pemerintah mengenai Permen ATR No.7/2016 yang hingga sampai saat ini peraturan tersebut belum terlaksana. 


\section{PENUTUP \\ KESIMPULAN DAN SARAN}

Penulis menyimpulkan bahwa Kesiapan Badan Pertanahan Nasional Kota Samarinda dalam penerbitan Sertifikat 1 (satu) lembar belum berjalan dengan semestinya sesuai yang di amanatkan menurut Permen ATR No 7/2016 tentang bentuk dan isi sertifikat 1 (satu lembar, adapun kesiapan Badan Pertanahan Nasional Kota Samarinda terkait penerbitan sertifikat 1 (satu) lembar antara lain sebagai berikut yaitu Kesiapan Organisasi, Kesiapan Sumber Daya Manusia (SDM), Kesiapan Sistem, Kesiapan Sarana dan Prasarana.

Kendala-kendala yang dihadapi Kesiapan Badan Pertanahan Nasional Kota Samarinda dalam penerbitan Sertifikat 1 (satu) lembar antara lain internal Badan Pertanahan Nasional Kota Samarinda mengenai kapasitas Badan Pertanahan Nasional Kota Samarinda seperti masalah belum terbitnya JUKNIS (Petunjuk Teknis), JUKLAK (Petunjuk Pelaksana), blanko pendaftaran tanah masih menggunakan blanko sertifikat sebelum di undangkannya Permen ATR No 7/2016.

Berdasarkan kesimpulan di atas, selanjutnya dapat diusulkan saran yang diharapkan akan bermanfaat yaitu bahwa untuk kesiapan panitia penerbitan Sertifikat 1 (satu) lembar Kantor Badan Pertanahan Nasional Kota Samarinda hendaknya segera diterapkan mengenai pelaksanaan peraturan perundang - undangan yang berkaitan mengenai penyeragaman penerbitan bentuk isi dan format Sertifikat yang baru setelah ditetapkannya Permen ATR No. 7/2016 tentang bentuk dan isi sertifikat 1 (satu) lembar dan perlu dilaksanakan secara bertahab sesuai yang amanat Pasal 1 dan 2 Permen ATR No. 7/2016 kepada pemerintah Badan Pertanahan Nasional
Kota Samarinda paling lama 2 tahun sejak berlakunya peraturan Menteri tersebut di undangkan. Dan Badan Pertanahan Nasional Kota Samarinda seharusnya segera menyeragagamkan peraturan perundang-undangan yang baru sehingga peraturan perundang-undang yang baru tidak hanya sebagai aturan yang diterbitkan namun tidak dijalankan dan Badan Pertanahan Nasiomal Kota Samarinda hendaknya meninjau kembali dari segi petujuk pelaksana dan petunjuk teknisnya yang dikeluarkan dari Menteri Agraria dan Tata Ruang agar Permen ATR No 7/2016 mengenai bentuk sertifikat 1 (satu) lembar bisa segera terlaksana.

\section{DAFTAR PUSTAKA}

\section{Buku/ Literatur:}

A.P. Parlindungan, Komentar Atas UUPA, Mandar Maju, Bandung, 1991

Pendaftaran Tantang Indonesia, Mandar Maju, Bandung, 2009

Beni Ahmad Soebani, Metode Penelitian Hukum, Pustaka Setia, Bandung, 2009

Boedi Harsono. Hukum Agraria Indonesia. Sejarah Pembentukan Undangundang Pokok Agraria, isi dan Pelaksanaannya, Djambatan, Jakarta, 2005

Dianto Bachriadi, Erpan Faryadi \& Bonnie Setiawan, Reformasi Agrari, Perubahan Politik, engketa dan agenda Pembaruan Agraria di Indonesia, Lembaga Penerbit 
Fakultas Ekonomi UI (Universitas Indonesia), Jakarta, 1997

Florianus SP Saangsun, TataCaraMengurus Sertifikat Tanah, Visimedia, Jakarta, 2007

Herman Hermit.Cara Memperoleh Sertipikat Tanah Hak Milik, Tanah Negara dan Tanah Pemda Teori dan Praktek Pendaftaran Tanah di Indonesia, Mandar Maju, Bandung, 2004

J.B Soesanto, Hukum Agraria, Semarang, Penerbit Fakultas Hukum Universitas 17 Agustus 1945 Semarang, 2011

Johnny Ibrahim, Teori dan Metode Penelitian Hukum Normatif, Bayumedia Publishing, Malang, 2006

Marzuki Mahmud Peter, Penelitian Hukum Edisi Revisi, Jakarta, Prenada Media Group, 2016

Mhd Yamin Lubis dan abd. Rahim Lubis, Hukum Pendaftaran Tanah, Ed.Rev, Medan, 2010

Samun Ismaya, Hukum Administrasi Pertanahan, Graha Ilmu, Yogyakarta, 2013

Tampil Ashari Siregar, Pendaftaran Tanah Kepastian Hak, Pustaka bangsa Press, Medan, 2005

Suratman dan Philips Dillah,Metode Penelitian Hukum, Alfabeta, Bandung, 2013

Urip Santoso, Hukum Agraria dan HakHak Atas Tanah, Kencana, Jakarta, 2010

\section{Perundang-undangan:}

Undang Undang Dasar 1945 Amandemen IV

Undang Undang Pokok Agraria Nomor 5 Tahun 1960 Peraturan Dasar PokokPokok Agraria

Peraturan Pemerintah Republik Indonesia Nomor 40 Tahun 1996 Tentang Hak Guna Usaha, Hak Guna Bangunan, dan Hak Pakai Atas Tanah

Peraturan Pemerintah Republik Indonesia Nomor 24 Tahun 1997 Tentang Pendaftaran Tanah

Peraturan Presiden Republik Indonesia Nomor 20 Tahun 2015 tentang Badan Pertanahan Nasional

Peraturan Menteri Agraria dan Tata Ruang/ Kepala Badan Pertanahan Nasional Republik Indonesia Nomor 7 Tahun 2016 Tentang Bentuk dan Isi Sertipikat Hak Atas Tanah

\section{Sumber Lain:}

www.bpn.go.id. Kementrian ATR/BPN Keluarkan Peraturan Sertipikat Satu Lembar, 12 Agustus 2017

www.eleveners.wordpress.com, SERTIPIKAT, 12 Agustus 2017

www.jurnalhukum.com, Sertipikat Sebagai Tanda Bukti Hak Atas tanah, 10 Agustus 2017

www.hukumproperty.com, Properti Indonesia - Bentuk Dan Isi Sertipikat Hak Atas Tanah, 10 Agustus 2017

www.bpn.go.id, Kementerian Agraria dan Tata Ruang/ Badan Pertanahan Nasional, 13 Agustus 2017 
http://wikipedia.org/wiki/Daftar_kecamatan _dan_kelurahan_di_kota_samarinda_ kecamatan_di_samarinda. Diakses pada 21 September 2017 